\title{
KEDUDUKAN HUKUM PUTUSAN NO. 200/PDT.G/2008/PN.SMG \\ DALAM PENYELESAIAN SENGKETA KEPEMILIKAN TANAH MELALUI PENDEKATAN RESTORATIVE JUSTICE
}

\author{
ADE ADRIANSYAH
}

\begin{abstract}
ABSTRAK
Tesis dengan judul "Kedudukan Hukum Putusan No. 200/Pdt.G/2008/PN.SMG Dalam Penyelesaian Sengketa Kepemilikan Tanah Melalui Pendekatan Restorative Justice" membahas putusan No. 200/Pdt.G/2008/PN.SMG dimana antara penggugat dan tergugat I, II, dan III para pihak mengambil jalan untuk berdamai dengan surat perjanjian perdamaian. Metode yang digunakan dalam penelitian ini ialah penelitian hukum yuridis normatif dan spesifikasi penelitian ini adalah deskriptif analitis. Sedangkan metode yang digunakan dalam pengumpulan data adalah metode library research. Hasil penelitian menyimpulkan bahwa : 1 . Kedudukan hukum atas Putusan No. 200/Pdt.G/2008/PN.SMG dalam penyelesaian sengketa kepemilikan tanah dapat diketahui dari Majelis Hakim Pengadilan Negeri Semarang dalam menjalankan tugasnya dengan baik dan juga telah menjalankan serta telah memenuhi Peraturan Mahkamah Agung Nomor 1 Tahun 2008 (PERMA) karena dalam hal ini PERMA sifatnya wajib dalam setiap Pengadilan Negeri yang dalam menangani kasus perdata yang dilakukan dengan cara mediasi, dan dalam hal ini telah dicantumkan beberapa pasal yang terkait dan sesuai dengan pokok permasalahan yang terdapat dalam kasus-kasus sengketa perdata. 2. Putusan No. 200/Pdt.G/2008/PN.SMG terkait penyelesaian sengketa sesuai dengan pendekatan Restorative Justice, secara hukum dapat diterima, bahwa keadilan restoratif dapat memberikan rasa keadilan yang memuaskan bagi para pihak yang bersengketa. Akan tetapi ditinjau dari sudut filosofis, teori keadilan restoratif tidak idealnya akan merumuskan sifat memuaskan dimana keadilan adalah kesamaan hak untuk semua orang di depan pengadilan.
\end{abstract}

Kata Kunci : Sengketa, Kepemilikan Tanah, Restorative Justice 


\title{
LEGAL STANDING OF DECISION NO. 200/PDT.G/2008/PN.SMG IN THE SETTLEMENT OF LAND OWNERSHIP DISPUTES THROUGH RESTORATIVE JUSTICE APPROACH
}

\begin{abstract}
ADE ADRIANSYAH
ABSTRACT

The thesis entitled "Legal Standing of Decision No. 200/Pdt.G /2008/PN.SMG In the Settlement of Land Ownership Disputes through Restorative Justice Approach" discusses the Decision No. 200/Pdt.G/2008/PN.SMG between the plaintiff and the defendant I, II, and III. All the parties agreed to settle the dispute through the peace agreement. The method used in this research was law juridical normative and the specification of this research is descriptive analytical. On the other hand, the method used in data collection was library research. The results of the study concluded that: 1. Legal standing of Decision No. 200/Pdt.G/2008/PN.SMG in the settlement of land ownership disputes can be known from the Panel of Judges of Semarang District Court in performing its duties well and also has run and complied with Supreme Court Regulation Number 1 Year 2008 (PERMA) because in this case PERMA is mandatory in every District Court in handling civil cases conducted by means of mediation. Further, this case has included several related articles and in accordance with the subject matter contained in cases of civil disputes. 2. Decision No. 200/Pdt.G/2008/PN.SMG related to dispute resolution is in accordance with the Restorative Justice approach, it is legally acceptable that restorative justice can provide a satisfactory sense of justice for the parties to the dispute. From a philosophical point of view, however, the theory of restorative justice does not ideally formulate a satisfactory nature in which justice is a common right for everyone before the court.
\end{abstract}

Keywords: Disputes, Land Ownership, Restorative Justice 


\section{PENDAHULUAN \\ Latar Belakang}

Masalah tanah merupakan masalah yang menyangkut hak rakyat yang paling dasar. ${ }^{1}$ Semakin kompleksnya kepentingan manusia dalam sebuah peradaban menimbulkan semakin tingginya potensi sengketa yang terjadi antar individu maupun antar kelompok dalam populasi sosial tertentu. Timbulnya sengketa sulit untuk dihindari bahkan tingkat probabilitasnya tidak sanggup dieliminasi sampai kepada titik nol. $^{2}$ Pertentangan, perselisihan dan perdebatan argumentatif merupakan salah satu upaya yang dilakukan manusia untuk mempertahankan pendirian dan pengakuan dalam proses pencapaian suatu kepentingan.

Guna menjamin kepastian hukum di bidang penguasaan dan pemilikan tanah faktor kepastian letak dan batas setiap bidang tanah tidak dapat diabaikan.Dari pengalaman masa lalu cukup banyak sengketa tanah yang timbul sebagai akibat letak dan batas bidang-bidang tanah tidak benar. Karena itu masalah pengukuran dan pemetaan serta penyediaan peta berskala besar untuk keperluan penyelenggaraan pendaftaran

1) Soedharyo Soimin, Status Hak dan Pengadaan Tanah, (Jakarta: Sinar Grafika, 1993), hlm. 82.

${ }^{2)}$ D.Y. Witanto, Hukum Acara Mediasi Dalam Perkara Perdata di Lingkungan Peradilan Umum dan Peradilan Agama Menurut PERMA No. 1 Tahun 2008 Tentang Prosedur Mediasi di Pengadilan, (Bandung: Alfabeta, 2011), hlm. 3. tanah merupakan hal yang tidak boleh diabaikan dan merupakan bagian yang penting yang perlu mendapat perhatian yang serius dan seksama, bukan hanya dalam rangka pengumpulan data penguasaan tanah tetapi juga dalam pengajian data pengusahaan/pemilikan tanah dan penyimpanan data tersebut.

Dalam Undang-undang Pokok Agraria tidak pernah disebutkan sertipikat tanah, namun seperti yang dijumpai dalam pasal 19 ayat (2) huruf $\mathrm{c}$ ada disebutkan "surat tanda bukti hak". Dalam pengertian seharihari surat tanda bukti hak ini sering ditafsirkan sebagai sertipikat tanah. ${ }^{3}$

Bila terjadi sengketa terhadap bidang tanah tersebut, maka oleh yang memiliki tanah, sertipikat yang ditangannyalah yang digunakan untuk membuktikan bahwa tanah itu miliknya.Surat tanda bukti hak atau sertipikat tanah itu dapat berfungsi menciptakan tertib hukum pertanahan serta membantu mengakrifkan kegiatan perekonomian rakyat (misalnya apabila sertipikat tersebut digunakan sebagai jaminan).Sebab yang namanya sertipikat Hak adalah tanda bukti atas tanah yang telah terdaftar oleh badan resmi yang sah dilakukan oleh Negara atas dasar Undang-undang.

Sehingga

pengeluaran sertipikat ini, menandakan telah ada

\footnotetext{
${ }^{3}$ Yamin Lubis dan Rahim Lubis, Hukum Pendaftaran Tanah, (Jakarta: Mandar Maju, 2008), hlm. 205.
} 
pendaftaran tanah yang dilakukan. Hanya saja, dalam praktek, penerbitan sertipikat tanah masih dapat dipertanyakan keefektifannya dalam memberikan kepastian dan perlindungan hukum, apakah sertipikat benar-benar melindungi hak (subyek) atau tanahnya (obyek) atau hanya bukti fisik sertipikatnya saja, karena sering terjadi ketika dibawa ke pengadilan, dapat saja diakui secara formal sertipikatnya, tetapi tidak melindungi subyek dan obyeknya. Peradilan Tata Usaha Negara dapat saja menolak menyatakan untuk membatalkan sertipikat tanah, tetapi peradilan umum menyatakan orang yang terdaftar namanya dalam sertipikat tidak berhak atas tanah yang disengketakan. ${ }^{4}$

Dalam putusan No. 200/Pdt.G/2008/PN.SMG antara Liliana Tedjosaputro sebagai penggugat dengan PT. Megah Realtyndo Indah, PT. Ajisaka, dan Kepala Kantor Pertanahan Kotamadya Semarang sebagai tergugat I, II, dan III. Dalam hal ini penggugat memiliki 2 bidang tanah dengan dasar kepemilikan yang termuat dalam SHM Nomor 19 dan 20, kedua bidang tanah terletak di desa Meteseh, Kecamatan Semarang Selatan, Kotamadya Semarang. Dalam duduk perkara menyatakan bahwa pada tahun 1997 tergugat III telah menerbitkan SHGB Nomor 1334 yang terletak di desa Meteseh, Kecamatan Semarang Selatan, Kotamadya Semarang

\footnotetext{
${ }^{4}$ Ibid.,hlm. 207.
}

yang mana sebagian tanahnya tumpang tindih dengan tanah penggugat yang termuat dalam SHM Nomor 19 dan 20. Selain itu sertifikat penggugat untuk HM No. 21 dan HM. 19 terbit terlebih dahulu dibandingkan dengan Sertifikat HGB atas nama tergugat I, tergugat II, dan tergugat III.

Setelah di ajukannya gugatan antara penggugat dan tergugat I, II, dan III para pihak mengambil jalan untuk berdamai dengan surat perjanjian perdamaian padahal dalam putusan No. 200/Pdt.G/2008/PN.SMG

Pengadilan Negeri Semarang telah menimbang dan mengadili gugatan tersebut. Kedudukan putusan pengadilan negeri Semarang hal ini masih dijadikan pertanyaan dimana putusan tersebut masih berlaku atau tidak jika terjadi perjanjian perdamaian antar penggugat dan para tergugat dikarena didalam peraturan maupun Undangundang belum menjelaskan atau menyatakan tentang hal tersebut.

Berdasarkan hal tersebut,penyelesaian sengketa pertanahan hal yang menjadi akhir dari penyelesaian kasus pertanahan tersebut ialah hasil dari kesepakatan para pihak yang berselisih, apakah berdamai ataukah tidak terhadap Sengketa tanah yang tidak berhasil diselesaikan dengan mediasi di luar pengadilan maka akan menempuh jalur litigasi di pengadilan. Berkaitan dengan penyelesaian sengketa yang menempuh di pengadilan maka 
terdapat aturan yang harus ditaati oleh setiap para pencari keadilan yang mengajukannya, dalam hal ini menggunakan hukum acara dalam prosesnya sesuai dengan yang telah ditetapkan.

Pada perdamaian oleh para pihak sebagaimana mestinya maka akan ada suatu perjanjian kesepakatan bersama yang dituangkan dalam bentuk tertulis, baik yang dilakukan di pengadilan maupun di luar pengadilan. Manakala hal ini dijadikan sebagai kepastian hukum bagi para pihak yang bersangkutan. Mengingat dalam negara hukum, hukum ditempatkan sebagai aturan main dalam penyelenggaraan kenegaraan, pemerintahan, dan kemasyarakatan, sementara tujuan hukum itu sendiri antara lain "...opgelegd om de samenleving vreedzaam, rechtvaardig, en doelmatig te ordenen"5 (diletakkan untuk menata masyarakat yang damai, adil, dan bermakna) artinya sasaran dari negara hukum adalah terciptanya kegiatan kenegaraan, pemerintahan, dan kemasyarakatan yang bertumpu pada keadilan, kedamaian, dan kemanfaatan atau kebermakanaan.

Berbeda halnya dengan keadilan restoratif yang merupakan bentuk penyelesaian di luar pengadilan untuk perkara pidana seperti, sedangkan perdamaian merupakan bentuk penyelesaian di luar pengadilan

5) Ridwan HR, Hukum Administrasi Negara, cet.ke-7, (Jakarta: Rajawali Pers, 2011), hlm. 22. untuk perkara perdata khususnya perkara No. 200/pdt.g/2008/PN.Smg.

Sementara menurut Erlyn Indarti menjelaskan, implementasi restorative justice memang perlu mengangkat atau selaras dengan kearifan lokal, sebab kearifan lokal terus hidup di tengah masyarakat. Adanya restoratifve Justiceyang mengedepankan kearifan lokal mengutamakan keselamatan publik yang dicapai melalui pemeliharaan perdamaian oleh seluruh elemen masyarakat. Dengan demikian, adanya pemberdayaan masyarakat dalam menuju restorative justice dari nilai-nilai yang ada pada masyarakat itu sendiri, akan efektif dalam membangun kamtibmas yang kondusif dan bermartabat. ${ }^{6}$

Berdasarkan hal-hal yang telah dipaparkan diatas maka penyusun tertarik untuk melakukan penelitian mengenai: "Kedudukan Hukum Putusan No. 200/Pdt.G/2008/PN.SMG Dalam Penyelesaian Sengketa Kepemilikan Tanah Melalui Pendekatan Restorative Justice"

\section{Metode Penelitian}

\section{Metode Pendekatan}

Penelitian

ini menggunakan metode penelitian dengan pendekatan yuridis sosiologis (social legal approach).Pendekatan yuridis sosiologis dimaksudkan sebagai

\footnotetext{
6) Seminar nasional polres klaten dalam rangka mengangkat kearifan lokal polmas dan penegakan hukum menuju restorative justice, dalam http://klaten.jateng.polri.go.id/ /, diakses pada tanggal 3 Februari 2017
} 
penerapan dan pengkajian hubungan aspek hukum dengan aspek non hukum dalam bekerjanya hukum di masyarakat.Dalam penelitian ini terdapat kasus kedudukan hukum Putusan No. 200/Pdt.G/2008/PN.SMG dalam penyelesaian sengketa kepemilikan tanah serta Putusan No. 200/Pdt.G/2008/PN.SMG terkait penyelesaian sengketa sesuai dengan pendekatan Restorative Justice.

\section{Spesifikasi Penelitian}

Spesifikasi penelitian yang digunakan dalam penelitian ini berupa penelitian deskriptif analitis.Metode deskriptif analitis merupakan merupakan metode penelitian dengan cara mengumpulkan data-data sesuai dengan yang sebenarnya kemudian data-data tersebut disusun, diolah dan dianalisis untuk dapat memberikan gambaran mengenai masalah yang ada. Deskriptif adalah untuk menggambarkan secara tepat individu, keadaan, gejala, atau kelompok tertentu, atau untuk menentukan penyebaran suatu gejala lain dalam masyarakat ${ }^{7}$.

\section{Sumber dan Jenis Data}

Sumber data dalam penelitian merupakan subjek dimana data yang diperlukan dalam penelitian diperoleh, dalam penelitian yang penulis susun sumber data yang digunakan adalah sumber data sekunder. Sumber data sekunder

7) Amirudin dan Zainal Asikin, Pengantar Metode Penelitian Hukum, (Jakarta: PT Raja GrafindonPersada, 2004), hlm. 2427. merupakan sumber data yang didapat dari keteranganketerangan atau pengetahuan secara tidak langsung melalui subtansi bahan kepustakaan, dokumen, arsip, literatur, serta tulisan-tulisan lain yang berhubungan dengan masalah yang akan dicari jawabannya dalam penelitian ini. Sumber data sekunder ada tiga jenis: ${ }^{8}$

a. Bahan hukum primer adalah bahan-bahan hukum yang mengikat dan dalam penelitian ini menggunakan:
1) Undang-Undang Dasar 1945;
2) Undang-Undang Nomor 5 Tahun 1960 tentang Pokok Agraria; Peraturan Dasar Pokok-
3) Peraturan Presiden Nomor. 20 Tahun 2015 tentang Badan Pertanahan Nasional;

4) Peraturan Menteri Negara Agraria/Kepala Badan Pertanahan Nasional Nomor 1 Tahun 1999 tentang Tata Cara Penanganan Sengketa Pertanahan;

5) Peraturan Kepala Badan Pertanahan Nasional Republik Indonesia Nomor 3 Tahun 2011 tentang Pengelolaan Pengkajian dan Penanganan Kasus Pertanahan.
6) Putusan No. 200 /Pdt.G/2008/PN.Smg

\footnotetext{
${ }^{8)}$ Peter Mahmud Marzuki, Pengantar IImu Hukum, (Jakarta: Kencana, 2008), hlm. 41.
} 
b. Bahan hukum sekunder yang memberikan penjelasan mengenai bahan hukum primer, seperti misalnya buku, rancangan undangundang, hasil-hasil penelitian, dan lain-lain. Dalam penelitian ini penulis menggunakan buku-buku yang berkaitan dengan penelitian.

c. Bahan hukum tersier yaitu bahan yang memberikan petunjuk maupun penjelasan terhadap bahan primer dan sekunder seperti kamus, ensiklopedia dan lain-lain. ${ }^{9}$

Selain itu, sumber data yang digunakan adalah sumber data primer. Sumber data primer merupakan sumber data yang mendukung untuk memberi keterangan yang membantu sumber data sekunder diperoleh secara langsung dari narasumber diantaranya pihak kepolisian, hakim pengadilan, pengacara di kota Semarang.

\section{Teknik Pengumpulan Data} Adapun teknik pengumpulan data yang digunakan oleh penulis dalam penelitian ini disesuaikan dengan fokus dan tujuan penelitian, yaitu studi pustaka (Library Research).Studi pustaka adalah penelitian yang dilakukan oleh peneliti dengan mengumpulkan sejumlah buku-buku, majalah, liflet yang berkenaan dengan masalah dan tujuan penelitian. Buku tersebut dianggap sebagai sumber data yang akan diolah dan dianalisis seperti banyak

\footnotetext{
9) Ibid.,hlm. 52.
}

dilakukan oleh ahli sejarah, sastra dan bahasa.

\section{Metode Analisis Data}

Analisis data yang digunakan oleh penulis dengan menggunakan metode analisis kualitatif. Analisis kualitatif adalah data yang diperoleh melalui penelitian lapangan maupun penelitian kepustakaan kemudian disusun secara sistematis, dan selanjutnya dianalisa secara kualitatif untuk mencapai kejelasan masalah yang akan dibahas $^{10}$. Penelitian analisis kualitatif merupakan kegitan analsisis data tidak melibatkan angka-angka atau rumus-rumus statiska, baik pada saat pengumpulan data maupun pada saat proses pengolahan atau analisis data. ${ }^{11}$

\section{HASIL PENELITIAN DAN PEMBAHASAN}

\section{A. Kedudukan hukum atas Putusan No. 200/Pdt.G/2008/PN.SMG dalam penyelesaian sengketa kepemilikan tanah $\mathrm{Di}$ dalam putusan} Pengadilan Negeri No. 200/Pdt.G/2008/PN.SMG, dapat diketahui bahwa dasar pertimbangan yang digunakan oleh Majelis Hakim dalam hal sengketa kepemilikan tanah adalah dari segi hukum (yuridis) dan dari segi non hukum (non yuridis).

\footnotetext{
10) Ibid.,hlm. 119.

11) Maman Abdurahman dan Sambas Ali Muhidin. Panduan Praktis Memahami Penelitian (Bidang Sosial-AdministrasiPendidikan, (Bandung : Pustaka Setia, 2011). HIm. 148.
} 
Berdasar dari segi hukum (yuridis), diketahui bahwa berdasarkan fakta-fakta yang ditemukan dipersidangan yaitu setelah menghubungkan antara keterangan saksi yang diajukan di depan persidangan, maupun keterangan dari tergugat, baik yang dibacakan di muka persidangan oleh kuasa hukum maupun saksi yang hadir di muka persidangan.Sengketa Perdata Nomor 200/Pdt.G/2008/PN.SMGyang telah diajukan Penggugat, menurut hakim Pengadilan Negeri Semarang sengketa perdata tersebut telah melakukan perbuatan melawan hukum, maka eksepsi Tergugat mengenai hal tersebut ditolak.

Dengan adanya unsurunsur perbuatan melawan hukum di dalam sengketa perdata pada putusan Pengadilan Negeri Semarang tersebut, menurut Sudikno Mertokusumo, bahwa Kekuasaan pengadilan dalam perkara perdata meliputi semua sengketa tentang hak milik atau hak-hak yang timbul karenanya, hutang-piutang atau hak-hak keperdataan lainnya ${ }^{12}$. Istilah perkara atau sengketa perdata lazim dikenal dan dipergunakan dalam bahasa sehari-hari. Namun, hingga saat ini belum terdapat definisi yang jelas dan tepat mengenai perkara perdata yang menurut Pasal 50 UndangUndang Nomor 2 Tahun 1986 masuk dalam lingkup kewenangan Badan Peradilan

\footnotetext{
${ }^{12)}$ Sudikno Mertokusumo, Hukum Acara Perdata Indonesia, (Yogyakarta: Liberty, 1998), hlm 27 - 28.
}

Umum. Definisi yang ada sekadar mengidentifikasi hubunganhubungan hukum atau objek apa saja yang masuk dalam perkara perdata dan menjadi lingkup kewenangan hakim atau pengadilan perdata.

$$
\text { Dalam mengajukan }
$$
gugatan harus dicantumkan apa yang menjadi dasar gugatan tersebut atau dasar tuntutan tersebut, sehingga dengan adanya dasar gugatan tersebut, menjadi landasan pemeriksaan dan penyelesaian perkara. Akan tetapi dalam pemeriksaan dan penyelesaian tidak boleh menyimpang dari dalil gugatan tersebut.Bahwa di dalam dasar gugatan itu tidak hanya dirumuskan peristiwa hukum yang menjadi dasar gugatan tetapi juga harus dijelaskan mengenai fakta-fakta yang mendahului adanya peristiwa hukum yang menjadi penyebab timbulnya peristiwa tersebut.

Pentingnya mediasi dalam konteks ini dimaknai bukan sekedar upaya untuk meminimalisir perkara-perkara yang masuk ke Pengadilan baik itu pada Pengadilan tingkat pertama maupun tingkat banding, sehingga badan peradilan dimaksud terhindar dari adanya timbunan perkara, namun lebih dari itu mediasi dipahami dan diterjemahkan dalam proses penyelesaian sengketa secara menyeluruh dengan penuh kesungguhan untuk mengakhiri suatu sengketa yang tengah berlangsung.

Walaupun dalam kenyataannya setiap perkara 
yang masuk ke Pengadilan Negeri sebagian besar tidak dapat didamaikan lagi dengan upaya perundingan, namun itu bukan berarti upaya ini kita matikan sama sekali, akan tetapi justru itu yang menjadi tantangan bagi mediator khususnya hakim untuk bisa memainkan perannya sebagai mediator yang ulung dengan menerapkan kemampuan dan kemahirannya secara maksimal.Oleh karena itu mediasi hendaknya dijadikan sebagai lembaga pertama dan terakhir dalam menyelesaikan sengketa antara para pencari keadilan.

Demikian halnya dengan sengketa perdata pada putusan Pengadilan Negeri Semarang No. 200/Pdt.G/2008/PN.SMG di atas, perkara ini secara garis besar mengambarkan sengketa kepemilikan tanah yang terjadi di wilayah hukum Pengadilan Negeri Semarang. Mengenai upaya penyelesaian sengketa tersebut sebelum putusan dilakukan dengan cara mediasi.

\begin{tabular}{llr}
\multicolumn{2}{c}{ Peraturan } & Mahkamah \\
Agung & Republik & Indonesia \\
(PERMA RI) Nomor 1 & Tahun \\
2008, menyebutkan bahwa
\end{tabular}
mediasi sudah dimasukkan ke dalam proses peradilan formal dalam Pasal 2 ayat (1) yang menegaskan bahwa semua perkara perdata yang diajukan ke pengadilan wajib didahulukan penyelesaian melalui perdamaian dengan bantuan mediator. Peraturan Mahkamah Agung Nomor 1 Tahun 2008 tentang Proses Mediasi harus memerlukan beberapa tahapan di antaranya adalah tahapan mengajukan pendaftaran perkara, penetapan hakim majelis.

Sesuai dengan Peraturan Mahkamah Agung No. 1 Tahun 2008 tentang Prosedur Mediasi di Pengadilan, proses penyelesaian sengketa melalui mediasi di Pengadilan Negeri Semarang dilakukan dengan tahapan pra mediasi dan tahap mediasi.

Penerapan mediasi sebagai salah satu cara alternatif penyelesaian sengketa tanah bagi masyarakat/para pihak yang bersengketa di Kota Semarang, Pengadilan Negeri Kota Semarang telah melaksanakan mediasi sesuai dengan Peraturan Mahkamah Agung Nomor 1 Tahun 2008 tentang Prosedur Mediasi di Pengadilan di atas. Akan tetapi, hasil jalan mediasi dalam perkara no. 200/Pdt.g/2008 PN.Smg tidak berhasil membuat kesepakatan perdamaian, oleh karena itu maka pemeriksaan perkara sengketa ini berujung ke Pengadilan Negeri Semarang.

Untuk dapat mencapai suatu kesepakatan atau titik temu dalam proses mediasi, banyak hambatan dan kendala-kendala yang menyertainya. Hambatan tersebut diantaranya kurangnya keterbukaan para pihak dalam mediasi, sikap para pihak yang tidak mau saling mengalah, ketidakhadiran para pihak dalam proses mediasi, kurangnya iktikad baik para pihak, peran kuasa hukum, kurangnya kemampuan hakim dalam memimpin jalannya mediasi, ketidaknetralan mediator, dan lain sebagainya. Dari sekian banyak 
kendala yang ada, maka putusan putusan no. 200/Pdt.g/2008.Pn.Smg dapat dilihat pada pertimbangan hukum sebagai berikut:

\section{Menimbang,}

bahwa perkara ini telah melalui proses mediasi dimana Sdr. YUNIARTO, $\mathrm{SH}$, Hakim Pengadilan Negeri Semarang, ditunjuk sebagai mediator, ternyata para pihak tidak berhasil membuat kesepakatan bahwa perkara ini selesai dengan perdamaian, oleh karena itu maka pemeriksaan perkara ini dilanjutkan dengan cara biasa, meskipun demikian Majelis tetap memberi kesempatan kepada pihak-pihak untuk berupaya agar perkara ini dapat diselesaikan dengan cara damai. ${ }^{13}$

\section{B. Putusan}

\section{0/Pdt.G/2008/PN.SMG terkait penyelesaian sengketa sesuai dengan pendekatan Restorative Justice}

Dalam putusan No. 200/Pdt.G/2008/PN.SMG antara Liliana Tedjosaputro sebagai penggugat dengan PT. Megah Realtyndo Indah, PT. Ajisaka, dan Kepala Kantor Pertanahan Kotamadya Semarang sebagai tergugat I, II, dan III. Dalam hal ini penggugat memiliki 2 bidang tanah dengan dasar kepemilikan yang termuat dalam SHM Nomor 19 dan 20, kedua bidang tanah terletak di desa Meteseh, Kecamatan Semarang Selatan,

13) Lihat putusan no.
200/Pdt.g/2008.Pn.Smg

Kotamadya Semarang. Dalam duduk perkara menyatakan bahwa pada tahun 1997 tergugat III telah menerbitkan SHGB Nomor 1334 yang terletak di desa Meteseh, Kecamatan Semarang Selatan, Kotamadya Semarang desa Meteseh yang mana sebagian tanahnya tumpang tindih dengan tanah penggugat yang termuat dalam SHM Nomor 19 dan 20. Selain itu sertifikat penggugat untuk HM No. 21 dan HM. 19 terbit terlebih dahullu dibandingkan dengan Sertifikat HGB atas nama tergugat I, tergugat II, dan tergugat III.

Penggugat

merasa

dirugikan atas adanya tumpang tindih kepemilikan tanah tersebut karena selaku Tergugat I telah membangun tanah tersebut sebagai sarana perumahan. Usaha tersebut sekarang telah dilanjutkan oleh selaku Tergugat II telah berkerja sama untuk melakukan perataan tanah diatas tanah penggugat. Penggugat menyatakan bahwa penggugat II telah melawan hukum.Sehingga penggugat meminta Tergugat I dan II untuk mengosongkan tanah tersebut serta tergugat I dan II diminta untuk bertanggungjawab atas kerugiannya.Selain itu, Penggugat meminta Tergugat I untuk mencabut HGB No. 1334 dari buku tanah yang berjalan.Berdasarkan bukti yang diberikan penggugat maka Pengadilan Negeri menyatakan bahwa menolak eksepsi dari para tergugat dan mengabulkan gugatan penggugat serta penggugat dinyatakan sebagai 
pemilik sah atas 2 (dua) bidang tanah tersebut. Selain itu SHGB No. 1334 yang tercatat atas nama Tergugat I adalah tidak sah dan tidak memiliki kekuatan mengikat.

Setelah di ajukannya gugatan antara penggugat dan tergugat I, II, dan III para pihak mengambil jalan untuk berdamai dengan surat perjanjian perdamaian padahal dalam putusan No. 200/Pdt.G/2008/PN.SMG

Pengadilan Negeri Semarang telah menimbang dan mengadili gugatan tersebut. Kedudukan putusan pengadilan negeri Semarang hal ini masih dijadikan pertanyaan dimana putusan tersebut masih berlaku atau tidak jika terjadi perjanjian perdamaian antar penggugat dan para tergugat dikarena didalam peraturan maupun Undangundang belum menjelaskan atau menyatakan tentang hal tersebut.

Dari uraian di atas kiranya menjadi jelas tentang kelebihan model keadilan restoratif dalam peradilan sengketa tanah di Indonesia. Namun jalan menuju ke sana memang tidak mudah karena menyangkut perspektif sistem peradilan itu sendiri. Maka yang pertama sekali harus dilakukan adalah membangunkan hasrat untuk mengubah paradigma yang ada dengan paradigma baru yang lebih beradab atau komitmen untuk melindungi korban dari adanya tumpang tindih kepemilikan tanah dalam proses peradilan. Beberapa langkah untuk menuju praktik keadilan restoratif harus dilakukan oleh pengadilan sebagaimana tersebut di bawah ini.

Pengadilan sebagai suatu institusi terakhir dalam hal menentukan putusan akan nasib seseorang dari hal ini menurut Mahrus Ali mengatakan bahwa "Selama ini, pengadilan masih dianggap sebagai bagian dari sistem hukum formal yang terlepas dari masyarakat", ${ }^{14}$ sehingga dari pendapat ini seharusnya pengadilan merubah cara pandangnya. Sebagai suatu institusi yang ditunjuk negara bahkan bisa dibilang ditunjuk oleh Tuhan untuk dapat memutus dengan hati nurani yang dipercayakan oleh Tuhan dan negara sebagaimana yang diatur dalam Undang-undang No. 48 Tahun 2009 tentang Kekuasaan Kehakiman dalam Pasal 4 ayat (1) dijelaskan "Peradilan dilakukan "Demi Keadilan Berdasarkan Ketuhanan Yang Maha Esa", hal ini sebagaimana diatur dalam Undang-undang No. 8 Tahun 1981 tentang Hukum Acara Pidana Pasal 197 ayat (1) butir a dituliskan "Kepala putusan yang dituliskan berbunyi "Demi Keadilan Berdasarkan Ketuhanan Yang Maha Esa", ${ }^{15}$ dari Undangundang No. 48 Tahun 2009 tentang Kekuasaan Kehakiman Pasal 4 ayat (1) dan sebagaimana juga diatur dalam Undang-undang No. 8 Tahun 1981 tentang Hukum Acara Pidana.

\footnotetext{
${ }^{14)}$ Mahrus Ali, Op Cit, hlm. 35.

${ }^{15)} R$. Soenarto Soerodibroto, KUHP dan KUHAP, (Jakarta: Rajagrafindo
} Persada, 2007), hlm. 197. 
Sehingga dari hal ini maka hakim secara tidak langsung bertanggung jawab langsung kepada Tuhan dalam memutus suatu perkara, sehingga hukum yang dimintakan oleh masyarakat yang merupakan bagian utama dari negara dan sebagai sumber dari hukum tersebut dapat menjadi suatu bahan pertimbangan dalam hal memutus, bukankah suara rakyat adalah suara Tuhan (voxpopulivox Del), sehingga sebagaimana yang telah diatur dalam Undang-undang No. 48 Tahun 2009 tentang Kekuasaan Kehakiman dalam Pasal 28 ayat (1) dituliskan bahwa "Hakim wajib menggali, mengikuti, dan memahami nilai-nilai hukum dan rasa keadilan yang hidup dalam masyarakat", 31 dan dalam ayat (2) dituliskan "Dalam pertimbangan berat ringannya pidana, hakim wajib memperhatikan pula sifat yang baik dan jahat dari terdakwa" dari kedua pasal ini menunjukan bahwa sebenarnya hakim dapat menarik dasar-dasar putusannya dari hukum yang bertumbuh dalam masyarakat,32 dan dari ayat (2) dari Undang-undang No. 48 Tahun 2009 ini dapat ditarik kesimpulan bahwa sebenarnya hakim telah diberikan kuasa untuk memutus dengan harus memperhatikan unsur-unsur etiket baik dari pada pelaku tindak pidana, sama seperti dalam perkara perbuatan melawan hukum dalam putusan perkara no. 200/Pdt.G/2008/PN.SMG, dimana para tergugat telah melakukan perbuatan melawan hukum sebenarnya telah terpenuhi unsur etiket baik yang tertuang dalam Pasal 28 ayat (2) dari Undang-undang No. 48 Tahun 2009 tentang Kekuasaan Kehakiman. Sehingga sebenarnya Undang-undang tidak menjadi suatu dasar utama dalam memutus suatu perkara pidana.

Dalam hal penerapan keadilan restorative dalam perkara penyelesaian sengketa kepemilikan tanah di mana dalam kasus ini yang menjadi obyek sengketa adalah 2 (dua) bidang tanah yaitu Sebidang tanah sebagaimana termuat dalam SHM Nomor 19 , seluas \pm 7.790 $\mathrm{m}^{2}$, terletak di desa Meteseh, Kecamatan Semarang Selatan, Kotamadya Semarang, Propinsi Jawa Tengah dan sebidang tanah sebagaimana termuat dalam SHM Nomor 21, seluas \pm $8.460 \mathrm{~m}^{2}$, terletak di desa Meteseh, Kecamatan Semarang Selatan, Kotamadya Semarang, Propinsi Jawa Tengahperlu pula adanya kepastian hukum yang di mana perlunya adanya keputusan hukum yang mengikat yang berasal dari lembaga yang benar-benar mewakili Tuhan bukan menjadi corong dari apa yang menjadi keinginan negara.

\section{KESIMPULAN}

1. Kedudukan hukum atas

Putusan No. 200/Pdt.G/2008/PN.SMG dalam penyelesaian sengketa kepemilikan tanah dapat diketahui dari Majelis Hakim Pengadilan Negeri Semarang 
dalam menjalankan tugasnya dengan baik dan juga telah menjalankan serta telah memenuhi Peraturan Mahkamah Agung Nomor 1 Tahun 2008 (PERMA) karena dalam hal ini PERMA sifatnya wajib dalam setiap Pengadilan Negeri yang dalam menangani kasus perdata yang dilakukan dengan cara mediasi, dan dalam hal ini telah dicantumkan beberapa pasal yang terkait dan sesuai dengan pokok permasalahan yang terdapat dalam kasuskasus sengketa perdata.Hal ini dapat dilihat dari Proses penyelesaian sengketa perdata kepemilikan tanah dengan cara mediasi yang dilakukan oleh Pengadilan Negeri Semarang, dalam hal ini ada dua tahap yang dilakukan dalam menyelesaikan sengketa perdata, yaitu: a) Tahap pra mediasi; dan b) Tahap Mediasi. Dari cara pertemuan mediasi tersebut melahirkan kesepakatan perdamaian yang berarti mediasi berhasil dan tidak melahirkan kesepakatan perdamaian yang berarti mediasi gagal. Hasil mediasi yang melahirkan kesepakatan perdamaian ini harus dibuat secara tertulis.

2. Putusan

No.

200/Pdt.G/2008/PN.SMG

terkait penyelesaian sengketa sesuai dengan pendekatan Restorative Justicesecara hukum dapat diterima, bahwa keadilan restoratif dapat memberikan rasa keadilan yang memuaskan bagi para pihak yang bersengketa. Selain itu keadilan restorative dengan metode penyelesaianya melalui mediasi penal tujuan utamanya berusaha untuk mengembalikan pada keadaan semula, hal ini telah membawa konsekuensi bagi kedua belah pihak yang berperkara agar menerima keputusan dengan rasa puas, adil dan tidak menimbulkan dendam dari kedua belah pihak. Adanya penyelesaian perkara melalui pola-pola pendekatan restoratif lebih mengedepankan proses musyawarah dan mufakat untuk mewujudkan hasil akhir yang memberikan rasa keadilan secara berimbang antara penggugat dan tergugat sehingga diharapkan dapat direalisasikan di dalamhukum yang dicita-citakan(ius constituendum)yang berlaku di masa mendatang

\section{DAFTAR PUSTAKA}

Amirudin dan Zainal Asikin, Pengantar Metode Penelitian Hukum, (Jakarta: PT Raja Grafindo Persada, 2004).

D.Y. Witanto, Hukum Acara Mediasi Dalam Perkara Perdata di Lingkungan Peradilan Umum dan 
Peradilan Agama Menurut PERMA No. 1 Tahun 2008 Tentang Prosedur Mediasi di Pengadilan, (Bandung: Alfabeta, 2011).

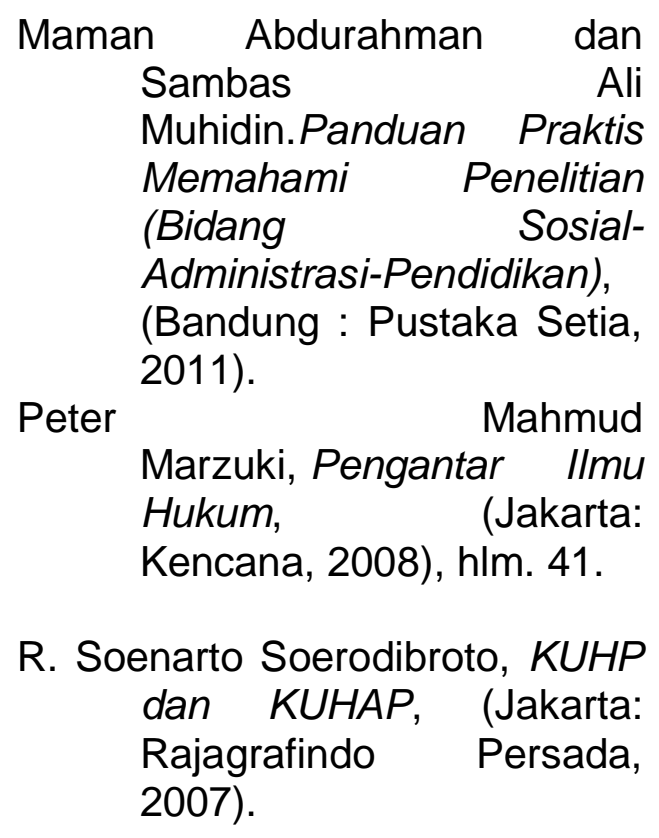

R. Soenarto Soerodibroto, KUHP dan KUHAP, (Jakarta: Rajagrafindo Persada, 2007).

Ridwan HR, Hukum Administrasi Negara, cet.ke-7, (Jakarta: Rajawali Pers, 2011).

Seminar nasional polres klaten dalam rangka mengangkat kearifan lokal polmas dan penegakan hukum menuju restorative justice, dalam http://klaten.jateng.polri.go. id/ /, diakses pada tanggal 3 Februari 2017

Soedharyo Soimin, Status Hak dan Pengadaan Tanah, (Jakarta: Sinar Grafika, 1993).

Sudikno Mertokusumo, Hukum Acara Perdata Indonesia, (Yogyakarta: Liberty, 1998).
Yamin Lubis dan Rahim Lubis, Hukum Pendaftaran Tanah, (Jakarta: Mandar Maju, 2008).

